\title{
Review
}

\section{The universal enemy: Jihad, empire, and the challenge of solidarity}

\author{
Darryl Li \\ Stanford University Press, Stanford, CA, 2020, 364pp., \\ ISBN: 978-105036-1087-3
}

Contemporary Political Theory (2022) 21, S27-S30. https://doi.org/10.1057/s41296021-00476-y; published online 23 February 2021

Darryl Li has written a book about terrorism that isn't actually about terrorism. He has written a book about jihad that isn't really about jihad. And he has written a book about the War on Terror that, directly anyway, says very little about that subject altogether.

This is not to say that $\mathrm{Li}$ has been dishonest or somehow misrepresented his subjects. It is rather to say that The Universal Enemy is a book that purports to examine familiar figures, terms, and tropes - the so-called terrorist or jihadi fighter, jihad, Islamic 'fundamentalism,' and the War on Terror - by refusing the governing logics and norms of the academic disciplines studying these phenomena - not to mention the classificatory practices of the imperial, security state to which these disciplines are all too often in service.

Li's understated side-stepping of these fields is not simply a critique of this complicity, although it surely is that. It is also a daring leap into a nearly illegible space of thinking and theorizing that challenges academic and policy orthodoxies by simply refusing to engage with them. As he says in the introduction, his book is 'directed primarily at those fellow travelers who already reject the demonization of Muslims, but who recognize that this is no substitute for serious conversations about political violence' (p. 25).

Instead of 'theorizing' 'jihad,' then, Li focuses empirically on the everyday reality of lives lived from below. Among many other things, $\mathrm{Li}$ is an anthropologist, and The Universal Enemy is largely an ethnographic study of participants in the pan-Muslim jihad in Bosnia in the 1980s and 1990s. Li describes this period of time as the ideological interregnum between the USA's great twentieth-century imperial projects: the Cold War and the War on Terror (Intercepted podcast, 2020).

Li's shift in perspective, geopolitical focus, and time period are all deftly indexed by the book's title, which is not at all about the 'universal enemy' - i.e., the terrorist or jihadi fighter - but rather about exposing the shallow, racist, and

(C) 2021 The Author(s), under exclusive licence to Springer Nature Limited part of Springer Nature. 14708914 Contemporary Political Theory Vol. 21, S1, S27-S30

www.palgrave.com/journals 
empirically useless categories of the War on Terror by looking at an unfamiliar jihad that scrambles many of that category's pre-existing notions and misconceptions. Centering a Muslim military endeavor in Eastern Europe during a time period before the 'official' War on Terror allows Li 'to think seriously about jihad on its own terms, and not simply as a demonic Other of the liberal state or a pale imitator of it' (p. 107, see also Li, 2015). It also allows him to challenge the racialization of Muslims as non-white by War on Terror policymakers, scholars, and other experts. Following his own advice that any study of jihad center 'a critical analysis of empire' (p. 26), Li usefully observes that, in addition to the too-easily-forgotten truisms that not all Muslims are Arab and not all Arabs are Muslim, we would do well to remember that not all Muslims are brown (or, we might add, Black), nor is Islam 'external' to either Europe or 'the West.' So much for the clash of civilizations.

Li offers this ethnography in service to the project of rethinking 'universalism' as something other than the sole property of a humanistic and liberal 'West.' Li's study presents the formation of a different set of universalisms orchestrated and managed within the terms of the Bosnian jihad that challenges both hegemonic human rights frames and the monolithic accounts of 'Islam' offered by liberal orders as essentially prone to violence or a convenient organizing form for otherwise stateless, violent actors who seek to overthrow Western domination. Li argues not only that universalisms are better understood as tenuous historical accomplishments constructed by a multiplicity of actors working only semipurposefully in concert, but also that no universalism is itself ever successfully uniform or hegemonic. Rather (or additionally), Li argues that one function of universalisms is to manage internal difference. That management employs a variety of different strategies beyond regulation or punishment, showcasing the variegated diversity of, in this case, practicing 'Islam' and participating in 'jihad' for a multinational cast of actors whose interests, loyalties, and solidarities do not conform to those presumed by a state-centric, liberal internationalist, and 'humanitarian' order.

Li's critical interrogation of universalisms will be less noteworthy to political theorists (who have studied this issue for some time now and are unlikely to naively accept any uncritical notion of 'the universal') than his intricate and careful reconstruction of the universalisms at work in the Bosnian jihad. In part I, Li presents a cast of characters who variously participated in the Bosnian jihad; each chapter provides a counter to the security state and terrorism studies. Chapter 1 offers a study of Abu 'Abd al-'Aziz, often taken to be the ideological mastermind behind summonses to Muslims around the world to participate in the Bosnian jihad. Presented by unreliable and ill-qualified terrorism 'experts' as a rootless and menacing (and the latter at least in part because of the former) al-Qaeda operative intent on spreading his influence beyond the Arab world, Li's portrait of this man tells a different story, which includes al-'Aziz's birth in Hyderabad, moving to Saudi Arabia with his family at age 11, and traveling to Afghanistan, Pakistan, and

S28 (c) 2021 The Author(s), under exclusive licence to Springer Nature Limited part of Springer Nature. 14708914 Contemporary Political Theory Vol. 21, S1, S27-S30 
then to Bosnia for both educational and professional reasons. Rather than a globetrotting Muslim, unaffiliated with a nation-state, ever in search of holy wars to wage, Li situates al-'Aziz's life against the backdrop of 'several generations of transregional migration around the Indian Ocean' (p. 37) and 'a distinctive kind of diasporic sensibility' (p. 42).

Chapter 2 intervenes in the limited, binary contrast between an Islam that derives from the Arab world - Salafism, in particular - and an Islam 'indigenous' to a secular Bosnian Muslim population (nationalized as 'Bosniak'). Li's focus in this chapter is on the circulation of texts and people between the Arab world and the Bosnian Katiba (Muslim fighting force). Unlike standard studies of jihad, which Li notes rely heavily on texts but very little on 'how those texts are actually produced and used in the world,' Li disputes Terrorism Studies' flat-footed assumptions that 'texts themselves are a kind of vector for ideology, delivered like missile payloads from centers of Islamic scholarship in the Arab world to the non-Arab periphery' (p. 69). Rather, the interchange between the Arab and Balkan Muslim worlds was infinitely more complex, defined less by a firm distinction between 'internal' and 'external' than an iterative struggle over the boundaries between nation and religion, the meaning of those boundaries, and various measures of piety as evidence of fitness for jihad.

Chapters 3 and 4 are even more provocative challenges to security state scholarship. In chapter 3, Li re-reads 'sovereignty' in the Bosnian jihad as a practice of solidarity within the Katiba. Backgrounding the state, Li asks us to think about both political bonds and political violence as a horizontal practice of mutual aid, rather than a unitary theory of top-down power wherein its highest exercise is sanctified as sovereignty. Chapter 4 presents a reading of Islam as neither religion nor culture but rather kinship and virtue. The kinship constituted by the Bosnian jihad produced relationships that included the heteronuclear family (e.g., marriage) but also exceeded it (e.g., brotherhood, community) while simultaneously flouting traditional distinctions between foreign and local. Li's reading of Muslim faith as virtue, or characterological excellence deemed particular to exemplars of Islam, is brilliant.

Part II of the book seems to promise a comparison of the Bosnian jihad's universalisms with three other universalisms: the Non-Aligned Movement (NAM), global peacekeeping, and the War on Terror. What is instead on offer are three different applications of the author's ethnographic approach. Thus, chapter 5 provides an account of participants in both the Bosnian Jihad and NAM; chapter 6 considers Arab and other global South Muslims as jihadis and/or peacekeepers in turn (without any apparent 'crisis' of conscience or loyalty); and chapter 7 foregrounds the ravages of the War on Terror in terms of the de-nationalization of Muslims - particularly Arab fighters in the Bosnian jihad.

This reader would certainly have appreciated a more pointed contrast of universalisms in the second half of the book, in order both to strengthen Li's case

(c) 2021 The Author(s), under exclusive licence to Springer Nature Limited part of Springer Nature. 1470- S29

8914 Contemporary Political Theory Vol. 21, S1, S27-S30 
for the distinctness of the Bosnian jihad and to amplify the contrasts between his own study of jihad and that of the others of which he is critical. But the refusal to deliver here is wholly in keeping with the overall approach of the book, which is at once a methodology, an ethics, and a praxis. Li's wager seems to be that direct confrontation with the toxic orthodoxies of the War on Terror may only shore up its hegemonic power; better to leave these behind in favor of a richer, more complex, ethnographic analysis that is also and necessarily a decisively anti-racist and antiimperial account of political violence and its participants. The Universal Enemy thus presents a challenge not only to the scholarly and policy expertise produced about 'terrorism' and 'jihad,' but also to the very practice of academic and political 'theorizing' about them in the first place.

\section{References}

Li, D. 2015. A Jihadism Anti-Primer. Middle East Report 276. https://merip.org/2015/12/a-jihadismanti-primer/.

Universal Enemy: Scholar Darryl Li on the Relationship Between Transnational Jihadists and U.S. Empire. Intercepted podcast, Dec. 30, 2020.

Publisher's Note Springer Nature remains neutral with regard to jurisdictional claims in published maps and institutional affiliations.

C. Heike Schotten

University of Massachusetts-Boston, Boston, MA 02125, USA

heike.schotten@umb.edu

C. Heike Schotten is Associate Professor of Political Science and the author of Queer Terror: Life, Death, and Desire in the Settler Colony (Columbia UP: 2018). 